Ann. Biol. anim. Bioch. Biophys., 1978, 18 (4), 759-765.

\title{
Sexual differences in Salmon gonadotropin
}

\author{
par B. BRETON, P. PRUNET, Pierrette REINAUD
}

Laboratoire de Physiologie des Poissons, I. N. R. A., 78350 jouy en Josas, France.

Summary. Salmon (Oncorhynchus tschawytscha) GTH's were purified from a mixture of pituitaries of both sexes or from separate male and female glands. Some of their biochemical, immunological and biological properties have been compared. These hormones differed essentially in amino acid composition, especially lysine, histidine and half cystine residues, and by the presence of $\alpha$-amino (or $\alpha$-aminoiso) butyric acid in male and GTH II preparations. The same differences were found between GTH I-II and GTH male-female. Observed biochemical differences were sex-linked; they did not influence immunological and qualitative biological effects, but could determine the affinity of the GTH of each sex or its specific receptors.

\section{Introduction.}

Recently, Idler et al. $(1975 a, b)$ isolated two gonadotropins (GTH) by chromatography on DEAE cellulose. One of these two GTH acted preferentially to stimulate ovarian C-AMP production in immature rainbow trout; the other stimulated testicular production of c-AMP. This was the first demonstration of the existence of two gonadotropins in the teleost pituitary using apparently different biological assays. BurzawaGerard (1973) in the carp, Donaldson ef al. (1972) in the salmon, and BurzawaGérard et al. (1975) in the sturgeon reported only one GTH, but it had never been shown that two different GTH were present when total gonadal tissues were used in studying in vitro C-AMP secretion by immature testis or ovary under pituitary stimulation.

In this work we have compared gonadoiropins isolated either from a mixture of pituitaries of both sexes or from isolated male and female pituitaries. Our object was to determine if the differences reported by Idler were sex-linked.

\section{Material and methods.}

Salmon (Oncorhynchus tschawytscha) pituitary glands were collected at the Cowlitz and Spring Creek hatcheries in the state of Washington (USA) during the 1975 spawning season.

The purification procedure was carried out according to Idler's method with a slight modification. The method included saline extraction in a Tris $0.05 \mathrm{M} \mathrm{NaCl}$ 
buffer, $\mathrm{pH} 7.6$; affinity chromatography on concanavaline $A$ sepharose in the same buffer ; gel filtration on ultrogel ACA 54 in Tris $0.05 \mathrm{NaCl} 0.15 \mathrm{M}, \mathrm{pH} 7.6$; ionexchange chromatography on DEAE cellulose biogel $A$ using a linear elution gradient of $\mathrm{NH}_{4} \mathrm{HCO}_{3}$ from $0.03 \mathrm{M}$ to $0.25 \mathrm{M}, \mathrm{pH}$ 8.0. The last step was gel filtration on ultrogel ACA 54 in $0.01 \mathrm{NH}_{4} \mathrm{CO}_{3}$ buffer, $\mathrm{pH} 8.0$.

Biological activities were measured according to Jalabert ef al. (1974). The following parameters were studied on the different preparations :

- Kd and apparent molecular weight after ultrogel ACA 54 chromatography ;

- electrophoretic pattern in polyacrylamide gel electrophoresis (PAGE) using 7.5 p. 100 acrylamide gel ; migration was done at $\mathrm{pH} 9.1$ under $2.5 \mathrm{~mA}$ per tube during 3 hrs ;

- immunological properties were studied either by immunoelectrophoresis and Ouchterlony immunodiffusion with an antibody produced against total salmon pituitary extract, or by radioimmunoassay (RIA). The technique was the same as that used for carp GTH (Breton et al., 1971). Each preparation was sfudied in competition reactions to the others with several antibodies to s-GTH. Antibodies were produced against pure t-GTH (Breton et al., 1976), partially purified salmon GTH (SG-G 100) (Donaldson ef al., 1972) and the pure female salmon GTH prepared in this experiment. Displacement curve slopes were studied by covariance analysis according to Snedecor and Cochran (1957).

Pituitary gonadotropin contents as measured either by RIA or bioassay were determined both in male and female pituitaries during a complete reproductive cycle to see if the immunological and biological properties of male and female GTH allowed similar determination of GTH pituitary levels using the same RIA system and a female bioassay for both sexes. Ten male and female rainbow trout were killed for

TABLE 1

Some chorocteristics of different solmon GTH's

\begin{tabular}{|c|c|c|c|c|}
\hline \multirow{2}{*}{ Characteristics } & \multicolumn{4}{|c|}{ Hormones } \\
\hline & 1 & II & female & male \\
\hline $\begin{array}{l}\text { (1) DEAE-c chromatography elution mola- } \\
\text { rities } \ldots \ldots \ldots \ldots \ldots \ldots \ldots \ldots \ldots \ldots \ldots\end{array}$ & 0.082 & 0.103 & 0.085 & 0.110 \\
\hline (2) Ultrogel ACA 54 chromatography : Kd & 0.30 & 0.31 & 0.305 & 0.30 \\
\hline ( $\left.{ }^{3}\right)$ Gel electrophoresis : band $\mathrm{Rf} \ldots \ldots$. & $\begin{array}{c}0.315-0.366 \\
0.387\end{array}$ & $\begin{array}{l}0.375-0.422 \\
0.45\end{array}$ & $0.41-0.47$ & $0.37-0.44$ \\
\hline (4) Arbitrary units of specific activity....... & 20 & 20 & 20 & 11 \\
\hline
\end{tabular}

(') : DEAE-c Diethylaminoethyl cellulose.

$\left({ }^{2}\right)$ : Kd : distribution coefficient.

$(3)$ : Rf : electrophoretic mobility.

(4) These units are defined as the dose ratio inducing 50 p. 100 oocyte maturation for the hormone and a stantard crude pituitary glycoprotein extract. 
determination each month throughout the reproductive cycle ; pituitary gonadotropin content was measured by RIA and bioassay. The results were analyzed by studying the correlations between the GTH values obtained by the two methods.

\section{Results.}

When gonadotropins were purified from a mixture of pituitaries of both sexes, two active fractions I and II were obtained after DEAE cellulose chromatography. Isolated male and female pituitaries gave only one peak of activity. The specific activities of the 4 hormones are given in table 1. I and II have similar activities, but GTH isolated from male pituitaries had half of the specific activity of the gonadotropin extracted from female pituitaries. Some biochemical characteristics of the 4 hormones are shown in table 1 . The immunological properties are the same for all the preparations ; immunoelectrophoresis and immunodiffusion showed only one precipitation line for each hormone with the antibody produced against total salmon pituitary extract ; the lines in the immunodiffusion test did not cross. In the RIA studied there are no statistical differences between the slope of the competition curves for hormone pairs obtained with the same antibody (table 2).

TABLE 2

RIA studies with different s-GTH preparations using two ontibodies

\begin{tabular}{|c|c|c|c|c|}
\hline $\begin{array}{c}\text { Antibody } \\
\text { raised against }\end{array}$ & $\begin{array}{l}\text { Labelled } \\
\text { s-GTH }\end{array}$ & Standard & Slope & Zero intercept \\
\hline \multirow{4}{*}{ t-GTH } & 우 & q & \multirow{2}{*}{$\begin{array}{c}-1.0213 \\
\text { NS } \\
-0.9998\end{array}$} & -2.0067 \\
\hline & 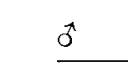 & $\hat{0}$ & & -1.8683 \\
\hline & $\overline{0}$ & $\pi$ & \multirow{2}{*}{$\begin{array}{c}-1.0831 \\
\text { NS } \\
-1.1286\end{array}$} & \\
\hline & t & q & & -1.7612 \\
\hline \multirow{4}{*}{ SG-G100 } & 우 & 우 & \multirow{2}{*}{$\begin{array}{r}-1.2289 \\
N S \\
-1.1859\end{array}$} & -0.9305 \\
\hline & 우 & $\hat{\sigma}$ & & -0.6954 \\
\hline & $0^{*}$ & $0^{*}$ & \multirow{2}{*}{$\begin{array}{c}-0.9479 \\
\text { NS } \\
-0.9930\end{array}$} & -1.1729 \\
\hline & $\sigma^{*}$ & 우 & & -0.9953 \\
\hline \multirow{6}{*}{ t-GTH } & 1 & I & \multirow{3}{*}{$\begin{array}{c}-0.9710 \\
\text { NS } \\
-1.0206 \mathrm{NS} \\
\mathrm{NS} \\
-0.9938\end{array}$} & -0.99402 \\
\hline & 1 & II & & -1.1835 \\
\hline & 1 & 우 & & -0.9382 \\
\hline & 11 & III & \multirow{3}{*}{$\begin{array}{c}-1.1443 \\
\text { NS } \\
-1.1847 \mathrm{NS} \\
\mathrm{NS} \\
-1.0994\end{array}$} & -0.9130 \\
\hline & II & 1 & & -0.9288 \\
\hline & II & $\pi$ & & -1.0418 \\
\hline
\end{tabular}


The aminoacid composition of the 4 hormones was also analyzed after 24-hr hydrolysis at $110^{\circ} \mathrm{C}$ in $\mathrm{HCl} 6 \mathrm{~N}$.

Table 3 shows the aminoacid compositions of the preparations compared with those of the hormone prepared by Pierce ef al. (1976) from the pituitary of the same species. The differences between I and II and male and female hormones were located in the lysine, histidine, half cystine and isoleucine residues. They were the same in the two pairs of hormones. Except for the half cystine residues, there was no important difference between s-GTH II, s-GTH male and Pierce's preparation.

TABLE 3

Amino acid compositions of different solmon gonadotropin preparation residues $/ 200$ residues.

\begin{tabular}{|c|c|c|c|c|c|}
\hline & $\begin{array}{c}\text { s-GTH } \\
\text { Pierce } \\
1976\end{array}$ & $\begin{array}{l}s-G T H I \\
\text { from a mixture }\end{array}$ & $\begin{array}{l}\text { s-GTH II } \\
\text { of pituitaries }\end{array}$ & $\begin{array}{c}\text { s-GTH } \\
\text { from isolated } \\
\text { O pituitaries }\end{array}$ & $\begin{array}{c}\text { s-GTH } \\
\text { from isolated } \\
\delta^{\lambda} \text { pituitaries }\end{array}$ \\
\hline Lysine & 11.8 & 19.7 & 11.8 & 20.4 & 12.4 \\
\hline Histidine. . & 5.4 & 10.2 & 7.6 & 9.6 & 6.4 \\
\hline Arginine. & 4.8 & 10.3 & 10. & 11.6 & 9.6 \\
\hline Aspartic Acid & 19.6 & 18.7 & 18.3 & 20. & 18 \\
\hline Threonine $\ldots \ldots \ldots \ldots \ldots$ & 22.4 & 20.3 & 20.5 & 18 & 21.4 \\
\hline Serine $\ldots \ldots \ldots \ldots \ldots$ & 11.8 & 10.2 & 11.7 & 10.2 & 13.2 \\
\hline Glutamic Acid $\ldots \ldots \ldots \ldots$ & 20.6 & 17.3 & 18.5 & 16.8 & 18 \\
\hline Proline $\ldots \ldots \ldots \ldots \ldots$ & 16.6 & 15 & 16 & 16 & 16.8 \\
\hline Glycine $\ldots \ldots \ldots \ldots \ldots$ & 9.4 & 9.1 & 8.7 & 8.6 & 9.8 \\
\hline Alanine................ & 7.6 & 7.5 & 6.3 & 7.4 & 6 \\
\hline Half Cystine.............. & 24.2 & 8.5 & 16.4 & 6.8 & 15.2 \\
\hline Valine...$\ldots \ldots \ldots \ldots$ & 13.0 & 14.2 & 14.1 & 14 & 16.4 \\
\hline Methionine............. & 4.2 & 5.0 & 4.8 & 5.2 & 4.2 \\
\hline Isoleucine $\ldots \ldots \ldots \ldots$ & 6.2 & 7.8 & 10.5 & 8.2 & 11.6 \\
\hline Leucine................ & 8.2 & 10.8 & 11.5 & 11.6 & 12 \\
\hline Tyrosine ............... & 8.0 & 10.3 & & 9.8 & \\
\hline $\begin{array}{l}\text { Tyrosine }+\alpha \text {-amino (iso) bu- } \\
\text { tyrique acid } . . . . . . . . . . .\end{array}$ & & & 11.4 & & 10 \\
\hline Phenylalanine...$\ldots \ldots$. & 5.4 & 5.4 & 6.0 & 4.9 & 6.6 \\
\hline
\end{tabular}

The I-female pair shows differences with this last preparation similar to those of pairs I-II and male-female. In addition, a compound was found in the s-GTH II-male pair that could be either $\alpha$-aminobutyric acid or $\alpha$-aminoisobutyric acid, as demonstrated after calibration of the aminolyzer. This product was not present in the other two hormones or in Pierce's preparation.

Comparisons of pituitary GTH levels by radioimmunoassay and bioassay gave a good correlation between the two values for the female but not for the male pituitary (table 4). The only statistically different results in the male were obtained during active spermatogenesis and spermiation at 5 p. 100 confidence limit when GTH pituitary content reached its maximum level. 
Table 4

Correlations between GTH level measured by radioimmunoassay and biological assay in the pifuitary of rainbow trout during the reproductive cycle.

In the two methods GTH contents were expressed in $\mu \mathrm{g} \mathrm{t-GTH-mg} \mathrm{fresh} \mathrm{tissue}$

\begin{tabular}{|c|c|c|c|c|c|c|c|c|}
\hline $\begin{array}{c}\begin{array}{c}\text { Stage of } \\
\text { (mean } \\
\text { oocytes) } \\
\text { diameter of }\end{array} \\
\text { oof } \ldots \ldots \ldots\end{array}$ & $0.5 \mathrm{~mm}$ & $0.5-1$ & $1-1-5$ & $1-5-2$ & $2-3$ & $3-4$ & $V G^{+}$ & Global \\
\hline $\begin{array}{l}\text { Correlation between } \\
\text { RIA s-GTH and s-GTH }\end{array}$ & 0.98 & 0.52 & 0.71 & 0.54 & 0.70 & 0.83 & 0.97 & 0.77 \\
\hline Statistical significance. . & $* * 1$ p. 100 & * 5 p. 100 & $* * 1$ p. 100 & NS & * 5 p. 100 & * 2 p. 100 & * 5 p. 100 & $* * 1$ p. 100 \\
\hline
\end{tabular}

\begin{tabular}{|c|c|c|c|c|c|c|c|c|c|}
\hline \multirow{2}{*}{$\begin{array}{l}\text { Stage of spermatogene- } \\
\text { sis.................. }\end{array}$} & 1 & II & III & IV & V & VI & VII & VIII & Global \\
\hline & \multicolumn{3}{|c|}{ resting spermatogenesis } & \multicolumn{5}{|c|}{ active spermatogenesis-spermiation } & \\
\hline $\begin{array}{l}\text { Correlation between } \\
\text { RIA s-GTH and BD s- } \\
\text { GTH } \ldots \ldots \ldots \ldots \ldots\end{array}$ & 0.0063 & -0.41 & -0.99 & 0.55 & 0.85 & 0.41 & 0.89 & 0.39 & 0.16 \\
\hline Statistical significance & NS & NS & NS & NS & * 5 p. 100 & NS & * 5 p. 100 & NS & NS \\
\hline
\end{tabular}

The RIA system used pure t-GTH (Breton ef al., 1976) and the antibody was produced against this preparation. The technique was the same as that described for carp GTH (Breton et al., 1971); here anti t-GTH was used at $1 / 210^{-5}$ concentration.

\section{Discussion.}

Most of the biochemical characteristics show similarities between GTH I-female and GTH II-male. The most important differences were noticed in their aminoacid compositions, and also in their electrophoretic mobilities, but they did not induce specific immunological properties.

Of the two factors isolated by Idler (1975b), one (corresponding to our first peak of activity) was preferentially active on ovarian c-AMP production in immature trout, and the other (corresponding to our fraction II) sitmulated c-AMP formation by the testis. Our results demonstrated biochemical identity between GTH l-female and GTH II-male. Thus, GTH from male and female pituitaries can be isolated from a mixture of pituitary on the basis of their different biochemical properties. Such sexlinked differences have already been reported for mammalian gonadotropins. They generally affect hexose and salic acid content. We have not measured these components in our preparations but there is another difference between male and female salmon GTH, never reported in mammals i.e. the presence of either $\alpha$-aminobutyric or $\alpha$-aminoisobutyric acid in the male hormone. Presently, we have no idea concerning the possible role of this compound. The biochemical differences between male and female GTH do not induce immunological differences, but they seem to have biological effects. GTH pituitary measurement during the whole reproductive cycle gave a good correlation between RIA and bioassay results for the female but not for the male des- 
pite the fact that the corresponding purified GTH has the same immunological preperties. This situation must be compared to the fact that highly purified male GTH has half the specific activity of the female gonadotropin when assayed on a female receptor as bioassay. On the other hand, Upadhyay (1977) was not able to demonstrate qualitative differences in the in vivo action of the male and female hormones at the ultrastructural level. They both initiated complete spermatogenesis in immature rainbow trout, but failed to induce total vitellogenesis after 10 weeks of treatment. Quantitative analysis remains to be done.

In conclusion, there may be some biochemical sex-linked differences in salmon gonadotropin isolated using in vitro trout oocyte maturation assay. These divergencies would permit chromatographic separation and could determine the affinity of each GTH for its specific receptors (ovaries or testis) without affecting their qualitative properties. They are of the same type and do not represent two distinct GTH's. These results do not reject the further existence of another GTH in fish pituitary.

Symposium sur la Reproduction des Poissons Paimpont, France, 19-21 septembre 1977.

Acknowledgments. - This work was supported by the CNEXO (Centre National pour l'Exploitation des Océans) grant No 77/1619.

Résumé. Les GTH de saumon (Oncorhynchus tschawtscha) ont été purifiées soit à partir d'un mélange d'hypophyses, soit à partir d'hypophyses mâles et femelles séparées. Certaines de leurs propriétés biochimiques immunologiques et biologiques ont été comparées. Ces hormones diffèrent essentiellement dans leurs compositions en acides aminés aux niveaux de leurs résidus en lysine, histidine, hémicystine et par la présence d'acide $\alpha$-aminobutyrique ou $\alpha$-aminoisobutyrique dans les préparations mâle et dans GTH II purifiée à partir d'un mélange d'hypophyses. Les mêmes différences sont retrouvées à la fois entre les préparations I, II et mâle, femelle. Les différences observées sont liées au sexe, et n'influent pas sur les propriétés immunologiques. Elles pourraient déterminer l'affinité de chaque GTH pour leurs récepteurs spécifiques.

\section{References}

BRETON B., KANN G., BURZAWA-GERARD E., BILLARD R., 1971. Dosage radioimmunologique d'une hormone gonadotrope de carpe (Cyprinus carpio L.). C. R. Acad. Sci. Paris, Série D, 272, $1515-1517$.

BRETON B., JALABERT B., REINAUD P., 1976. Purification of gonadotropin from rainbow trout (Salmo gairdneri Richardson) pituitary glands. Ann. Biol. anim. Bioch. Biophys., 16, 25-36.

BURZAWA-GÉRARD E., 1973. Efude biologique et biochimique de l'hormone gonadotrope d'un poisson téléostéen, la carpe (Cyprinus carpio L.). Thèse doct. Ełat, Sci. Nat., Paris VI, 123 pp.

BURZAWA-GÉRARD E., GONCHAROV B. F., FONTAINE Y. A., 1975. L'hormone gonadotrope hypophysaire d'un poisson chondrostéen, l'Esturgeon (Acipenser stellatus Pall.). I. - Purification. Gen. comp. Endocr., 27, 289-295.

DONALDSON E. M., YAMAZAKI F., DYE H. M., PHILLEO W. W., 1972. Preparation of gonadotropin from salmon (Oncorhynehus tschawytscha) pifuitary glands. Gen. comp. Endocr., 18, 469-481.

IDLER D. R., BAZAR L. S., HWANG S. J., 1975a. Fish gonadotropin(s). II. - Isolation of gonadotropin(s) from chum salmon pituitary glands using affinity chromatography. Endocr. Res. Communic., 2, 215-235.

IDLER D. R., BAZAR L. S., HWANG S. J., 1975b. Fish gonadotropin(s). III. - Evidence for more than one gonadotropin in chum salmon pituitary glands. Endocr. Res. Communic., 2, 237-249. 
JALABERT B., BRETON B., BILLARD R., 1974. Dosage biologique des hormones gonadotropes de poisson par le test de maturation in vitro des ovocytes de truite. Ann. Biol. onim. Bioch. Biophys., 14, 217-228.

PIERCE J. G., FAITH M. R., DONALDSON E. M., 1976. Antibodies to reduced s-carboxymethylated alpha subunit of bovine luteinizing hormone and their application to study of the purification of gonadotropin from salmon (Oncorhynchus tschawytscha) pituitary glands. Gen. comp. Endocr., 30, 47-60.

SNEDECOR G. W., COCHRAN W. G., 1957. Statistical methods. lowa State Univ. Press, Ames, lowa.

UPADHYAY S. N., 1977. Morphologie des gonades immatures ef étude expérimentale de l'induction de la gamétogenèse chez la Truite Arc-en-ciel (Salmo gairdneri R.). Thèse Doct. Etat Sci. Nat., Paris VI $111 \mathrm{pp}$. 